\title{
Study of Biogenic and $\alpha, \omega$-Polyamines by Combined Inelastic Neutron Scattering and Raman Spectroscopies and by Ab Initio Molecular Orbital Calculations
}

\author{
M. Paula M. Marques, ${ }^{*},+*$ Luís A. E. Batista de Carvalho, ${ }^{\ddagger}$ and John Tomkinson ${ }^{\S}$ \\ Unidade I\&D "Química-Física Molecular”, Faculdade de Ciências e Tecnologia, Universidade de Coimbra, \\ P-3049 Coimbra, Portugal, Dep. Bioquímica, Faculdade de Ciências e Tecnologia, Universidade de Coimbra, \\ P-3049 Coimbra, Portugal, and ISIS Facility, The Rutherford Appleton Laboratory, Chilton, United Kingdom
}

Received: September 17, 2001; In Final Form: December 13, 2001

\begin{abstract}
A study of the biogenic polyamines spermidine and spermine, as well as of the diamines $\mathrm{H}_{2} \mathrm{~N}\left(\mathrm{CH}_{2}\right)_{n} \mathrm{NH}_{2}$ ( $n=2-10$ and $n=12$ ), was carried out by both inelastic neutron scattering (INS) and Raman spectroscopies, for both their undeuterated and N-deuterated forms. Ab initio density functional theory (DFT) methods were also used, to obtain the calculated vibrational spectra of those molecules. A thorough vibrational analysis was performed, leading to the assignment of the solid-state spectra, both Raman and INS, of the polyamines studied, comprising all their longitudinal acoustic modes (LAM's).
\end{abstract}

\section{Introduction}

Polyamines are found in millimolar concentrations in most living cells (where they result from the decarboxylation of basic amino acids). They are intrinsic polycations essential for cell growth and differentiation. ${ }^{1-6}$ In particular, putrescine (1,4-diaminobutane, $\mathrm{H}_{2} \mathrm{~N}\left(\mathrm{CH}_{2}\right)_{4} \mathrm{NH}_{2}$ ), which is the first biogenic amine in the polyamine pathway, biosynthesised from arginine and the precursor of spermidine $\left(\mathrm{H}_{2} \mathrm{~N}\left(\mathrm{CH}_{2}\right)_{3} \mathrm{NH}\left(\mathrm{CH}_{2}\right)_{4} \mathrm{NH}_{2}\right)$ and spermine $\left(\mathrm{H}_{2} \mathrm{~N}\left(\mathrm{CH}_{2}\right)_{3} \mathrm{NH}\left(\mathrm{CH}_{2}\right)_{4} \mathrm{NH}\left(\mathrm{CH}_{2}\right)_{3} \mathrm{NH}_{2}\right)$, is widely distributed in both prokaryotic and eukaryotic cells. On account of absolute polyamine requirement for cell growth, interference with polyamine biosynthesis can be a rather promising therapeutical approach against proliferative diseases. In fact, an increased rate of those biosynthetic reactions has been unequivocally demonstrated in malignant processes. ${ }^{7-11}$ Also, deregulated polyamine biosynthesis is a well recognized characteristic of animal and human cancers. ${ }^{12}$ Moreover, it was verified that linkage of some of these molecules to previously tested anticancer drugs leads to a higher cytotoxic effect ${ }^{13}$ and, in some cases, even to an enhancement of the efficacy of the long used first-generation drug cisplatin (cis-diaminedichloroplatinum(II)). The antitumor effect of polyamines and some of their metal complexes (e.g. Pt(II) or Pd(II)) is thought to be due to DNA rearrangements induced by binding of these compounds, which is strongly conformation dependent. However, the exact nature of the biochemical mechanisms underlying this biological activity is still unknown.

The conformational preferences of alkylamines depend on different factors, from steric, dipolar, and hyperconjugative effects to the relative importance of intra- vs intermolecular interactions, namely hydrogen-bond type close contacts, which were shown to have a determinant stabilizing role in linear amines. ${ }^{14-16}$ There is presently no published work, at a molecular level, leading to a knowledge of the structure-activity relationship of such biologically relevant molecules. However, this would be of the utmost importance for understanding the

\footnotetext{
† Dep. Bioquímica, Universidade de Coimbra.

† Unidade I\&D "Química-Física Molecular", Universidade de Coimbra

$\S$ The Rutherford Appleton Laboratory.
}

biochemical mechanisms through which they act in living organisms, either in the regulation of normal cell growth and differentiation or in the cytotoxic effect of third-generation polyamine-derived anticancer drugs. Apart from a Raman and IR study reported on spermidine and spermine interactions with hydrochloric and phosphoric acids, ${ }^{17}$ only a preliminary assignment of the Raman spectrum of putrescine (in aqueous solution) is available. ${ }^{18} \mathrm{~A}$ conformational analysis of the small, linear amines 1,2-diaminoethane, ${ }^{19}$ 1,3-diaminopropane, ${ }^{20}$ and 1,4-diaminobutane (putrescine) ${ }^{21}$ by either ab initio calculations or Raman spectroscopy, will prove very useful as a model in the present study of the larger analogues.

INS is a well suited technique for the study of hydrogenous material. Indeed, since neutrons have a mass similar to that of the hydrogen atom, an inelastic collision between them involves a significant transfer of both momentum, $Q\left(\AA^{-1}\right)$ and energy to the irradiated sample. The scattering cross-section, $\sigma$, which is a characteristic of each element and does not depend on its chemical environment, is 80 barns for hydrogen as opposed to 5 barns for most other elements. Therefore, the modes involving a significant hydrogen displacement will dominate the spectrum. The intensity of each molecular vibrational transition $\left(I_{i}\right)$ follows the equation

$$
I_{i} \propto Q^{2} U_{i}^{2} \exp \left(-Q^{2} U_{\text {total }}^{2}\right) \sigma
$$

where, for each vibrational mode, $i, U_{i}$ stands for the amplitude of vibration of the atoms in this mode and $U_{\text {total }}$ represents the total amplitude of the atom in all the modes. The exponential term, $\exp \left(-Q^{2} U_{\text {total }^{2}}\right)$ is the well-known Debye-Waller factor, and to reduce its impact on the observed intensity the samples are cooled below $50 \mathrm{~K}$.

The LAM's $n$ (longitudinal acoustic modes with $n$ nodes) are low-frequency modes detected between ca. 50 and $600 \mathrm{~cm}^{-1}$, corresponding to in-plane expansions or contractions of all the $\mathrm{CCC}$ and $\mathrm{CCN}$ bond angles. The full longitudinal acoustic mode INS spectrum of a linear alkane was first determined for octadecane $^{22}$ and the whole set of LAM's for the 5-25n-alkanes have been recently observed and assigned. ${ }^{23}$ The spectral region 
<smiles>[R]C(=O)C(=O)C(=O)O</smiles>

(a)

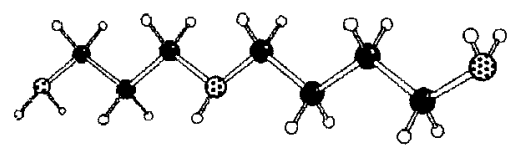

(b)

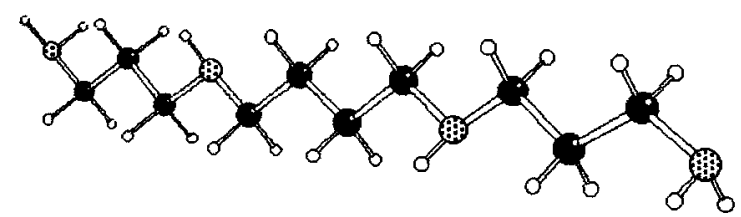

(c)

Figure 1. Schematic representation of the all-trans conformations of some of the polyamines studied in this work: (a) 1,4-diaminobutane; (b) spermidine; (c) spermine.
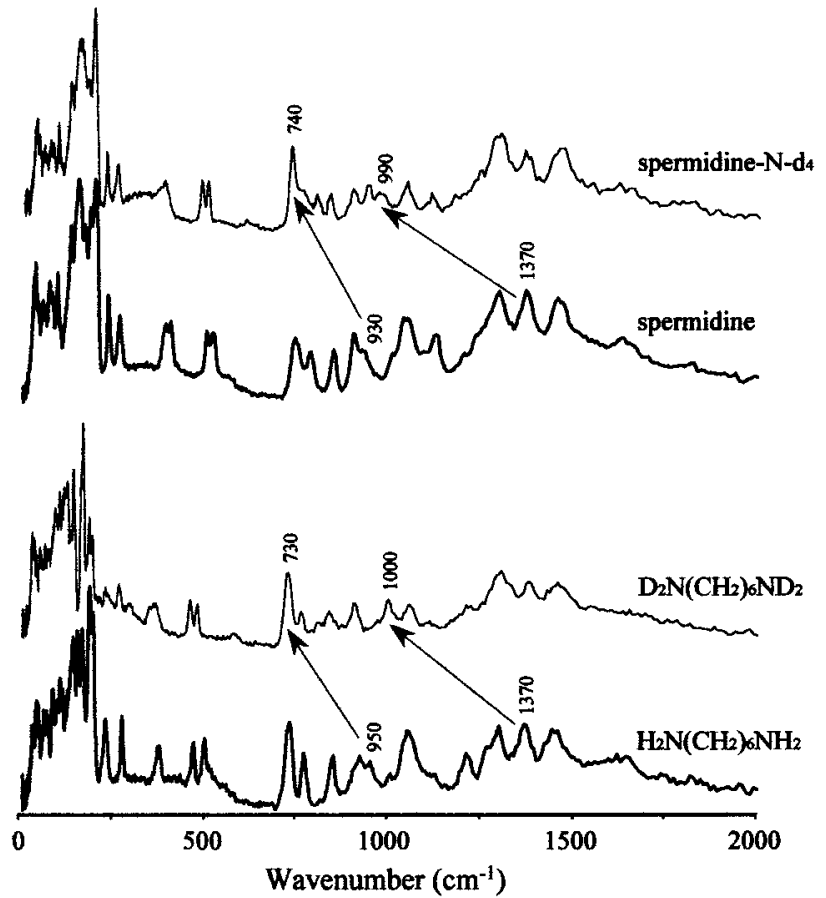

Figure 2. Experimental INS spectra $\left(16-2000 \mathrm{~cm}^{-1}\right.$, at $\left.20 \mathrm{~K}\right)$ for two distinct polyamines, in their undeuterated and $\mathrm{N}$-deuterated forms.

below ca. $200 \mathrm{~cm}^{-1}$ contains mainly out-of-plane tranverse acoustic modes (TAM's), which will not be discussed in this work.

In the present work, a study of the homologous series of $\alpha, \omega-$ diamines $\left(\mathrm{H}_{2} \mathrm{~N}\left(\mathrm{CH}_{2}\right)_{n} \mathrm{NH}_{2}\right)(n=2-10$ and $n=12)$, as well as of the polyamines spermidine $\left(\mathrm{H}_{2} \mathrm{~N}\left(\mathrm{CH}_{2}\right)_{3} \mathrm{NH}\left(\mathrm{CH}_{2}\right)_{4} \mathrm{NH}_{2}\right)$ and spermine $\left(\mathrm{H}_{2} \mathrm{~N}\left(\mathrm{CH}_{2}\right)_{3} \mathrm{NH}\left(\mathrm{CH}_{2}\right)_{4} \mathrm{NH}\left(\mathrm{CH}_{2}\right)_{3} \mathrm{NH}_{2}\right)$, was undertaken by vibrational spectroscopy (Raman and INS) combined with ab initio DFT calculations. The N-deuterated forms of those molecules were also studied.

\section{Experimental Section}

2.1. INS Spectroscopy. The INS spectra were obtained in the Rutherford Appleton Laboratory (Chilton, United Kingdom), at the ISIS pulsed neutron source on the TOSCA spectrometer. This is an indirect geometry time-of-flight, high-resolution $((\Delta E / E)$ ca. $2 \%)$, broad range spectrometer (more details are available elsewhere ${ }^{24}$ ). Solid compounds $(2-3 \mathrm{~g}$ each) were wrapped in aluminum foil, while the liquids were placed in thinwalled aluminum cans, which filled the beam. The samples were

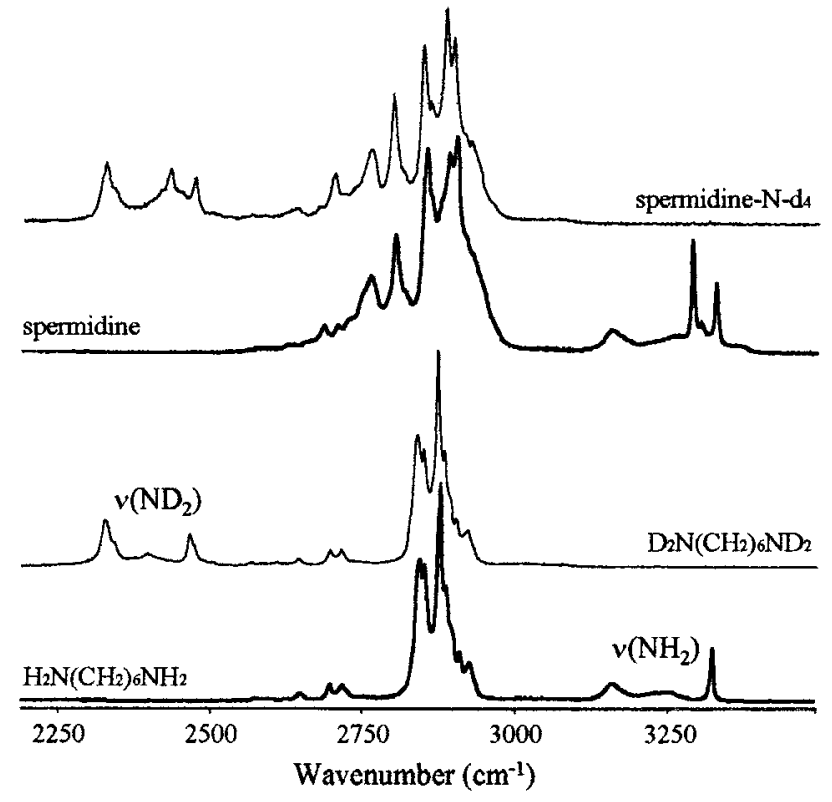

Figure 3. Experimental Raman spectra $\left(2200-3500 \mathrm{~cm}^{-1}\right)$ for two distinct polyamines (in the solid state), in their undeuterated and $\mathrm{N}$-deuterated forms.

TABLE 1: Experimental and Calculated Wavenumbers $\left(\mathrm{cm}^{-1}\right)$ for 1,2-Diaminoethane $\left(C_{2 h}\right)$ in the Low-Frequency Region

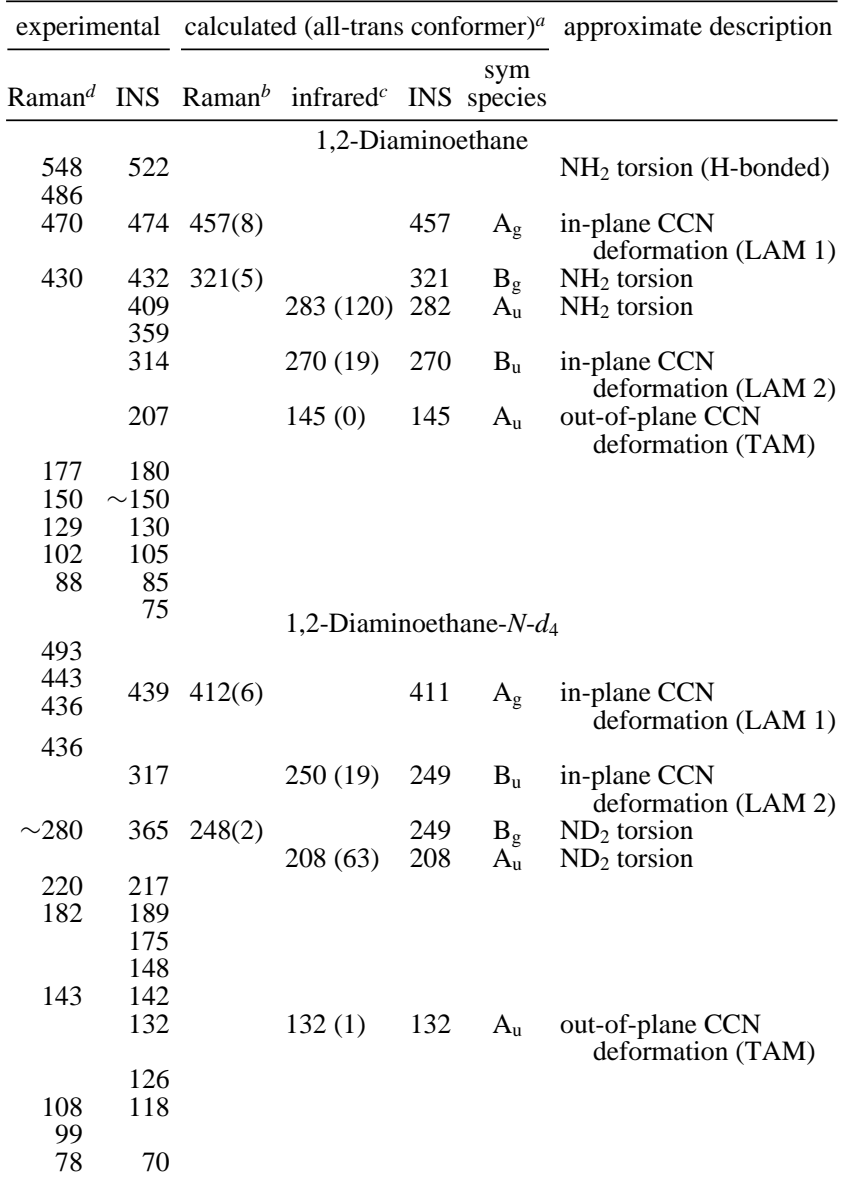

${ }^{a} \mathrm{~B} 3 \mathrm{LYP} / 6-31 \mathrm{G}^{*}$ level of calculation. ${ }^{b}$ Raman scattering activities in $\AA \cdot \mathrm{amu}^{-1}$. ${ }^{c}$ IR intensities in $\mathrm{km} \cdot \mathrm{mol}^{-1}$. ${ }^{d}$ Reference 19 .

cooled to ca. $20 \mathrm{~K}$. Data were recorded in the energy range $16-4000 \mathrm{~cm}^{-1}$ and converted to the conventional scattering law, $S(Q, v)$, vs energy tranfer (in $\mathrm{cm}^{-1}$ ) through standard programs. 
TABLE 2: Experimental and Calculated Wavenumbers $\left(\mathrm{cm}^{-1}\right)$ for 1,3-Diaminopropane $\left(C_{2 v}\right)$ in the Low-Frequency Region

\begin{tabular}{|c|c|c|c|c|c|c|}
\hline Raman & INS & $\operatorname{Raman}^{b}$ & infrared $^{c}$ & \multicolumn{2}{|c|}{$\begin{array}{c}\text { sym } \\
\text { INS } \\
\text { species }\end{array}$} & proxımate desc \\
\hline \multicolumn{7}{|c|}{ 1,3-Diaminopropane } \\
\hline & $\begin{array}{l}527 \\
465\end{array}$ & $444(1)$ & $444(15)$ & 444 & $\mathrm{~B}_{2}$ & $\begin{array}{l}\mathrm{NH}_{2} \text { torsion }(\mathrm{H} \text {-bonded) } \\
\text { in-plane } \mathrm{CCN} \text { deformation } \\
\quad(\mathrm{LAM} 2)\end{array}$ \\
\hline 432 & & $\begin{array}{l}301(5) \\
300(1)\end{array}$ & \multirow{2}{*}{$300(105)$} & $\begin{array}{l}301 \\
301\end{array}$ & $\begin{array}{l}\mathrm{A}_{2} \\
\mathrm{~B} 1\end{array}$ & $\mathrm{NH}_{2}$ torsion \\
\hline 423 & 409 & $397(10)$ & & 397 & $\mathrm{~A}_{1}$ & $\begin{array}{l}\text { in-plane CCN deformation } \\
\text { (LAM 1) }\end{array}$ \\
\hline$\sim 250$ & 248 & $183(1)$ & $183(4)$ & 183 & $\mathrm{~A}_{1}$ & $\begin{array}{l}\text { in-plane CCN deformation } \\
\text { (LAM 3) }\end{array}$ \\
\hline \multicolumn{7}{|l|}{$\begin{array}{l}218 \\
201\end{array}$} \\
\hline \multirow[b]{2}{*}{180} & 191 & $126(0)$ & $126(0)$ & 125 & $\mathrm{~A}_{2}$ & $\begin{array}{l}\text { out-of-plane CCN } \\
\text { deformation (TAM) }\end{array}$ \\
\hline & $\begin{array}{l}180 \\
174 \\
150\end{array}$ & & \multirow[t]{6}{*}{$119(5)$} & \multirow[t]{6}{*}{120} & \multirow[t]{6}{*}{$\mathrm{B}_{1}$} & \multirow[t]{6}{*}{$\begin{array}{l}\text { out-of-plane CCN } \\
\text { deformation (TAM) }\end{array}$} \\
\hline 137 & 134 & & & & & \\
\hline \multirow[t]{2}{*}{124} & 120 & & & & & \\
\hline & 101 & & & & & \\
\hline 92 & 87 & & & & & \\
\hline 82 & 77 & & & & & \\
\hline \multicolumn{7}{|c|}{ 1,3-Diaminopropane- $N$ - $d_{4}$} \\
\hline \multirow[t]{2}{*}{411} & 428 & $406(1)$ & \multirow[t]{2}{*}{$406(25)$} & 405 & $\mathrm{~B}_{2}$ & $\begin{array}{l}\text { in-plane CCN deformation } \\
\text { (LAM 2) }\end{array}$ \\
\hline & 406 & $375(8)$ & & 375 & $\mathrm{~A}_{1}$ & $\begin{array}{l}\text { in-plane CCN deformation } \\
\text { (LAM 1) }\end{array}$ \\
\hline \multirow[t]{2}{*}{324} & & $235(2)$ & & 232 & $\mathrm{~A}_{2}$ & $\mathrm{ND}_{2}$ torsion \\
\hline & & & $230(51)$ & 232 & $\mathrm{~B}_{1}$ & $\mathrm{ND}_{2}$ torsion \\
\hline$\sim 235$ & $d$ & $171(1)$ & $171(3)$ & 171 & $\mathrm{~A}_{1}$ & $\begin{array}{l}\text { in-plane CCN deformation } \\
\text { (LAM 3) }\end{array}$ \\
\hline \multicolumn{7}{|r|}{ (2010) } \\
\hline 191 & $d$ & & $115(5)$ & 112 & $\mathrm{~B}_{1}$ & $\begin{array}{l}\text { out-of-plane CCN } \\
\text { deformation (TAM) }\end{array}$ \\
\hline 172 & $d$ & $110(0)$ & $110(0)$ & 112 & $\mathrm{~A}_{2}$ & $\begin{array}{l}\text { out-of-plane CCN } \\
\text { deformation (TAM) }\end{array}$ \\
\hline 139 & 141 & & & & & \\
\hline \multicolumn{7}{|c|}{124} \\
\hline \\
\hline \multicolumn{7}{|l|}{80} \\
\hline
\end{tabular}

${ }^{a}$ B3LYP/6-31G* level of calculation. ${ }^{b}$ Raman scattering activities in $\AA \cdot \mathrm{amu}^{-1}$. ${ }^{c}$ IR intensities in $\mathrm{km} \cdot \mathrm{mol}^{-1} .{ }^{d}$ Not observed due to glassy nature of the sample.

2.2. Raman Spectroscopy. The Raman spectra performed at room temperature were obtained on a Spex Ramalog 1403 double spectrometer (focal distance $0.85 \mathrm{~m}$, aperture $f / 7.8$ ) equipped with holographic gratings of 1800 grooves $\cdot \mathrm{mm}^{-1}$ and a detector assembly containing a thermoelectrically cooled Hamamatsu R928 photomultiplier tube. The spectrometer operated with slits of $320 \mu \mathrm{m}$ and $1 \mathrm{~cm}^{-1} \mathrm{~s}^{-1}$. Below room temperature (ca. $220 \mathrm{~K}$ ), a homemade Harney-Miller type assembly was used, in a triple monochromator Jobin-Yvon T64000 Raman system (0.640 m, f/7.5) with holographic gratings of 1800 grooves $\cdot \mathrm{mm}^{-1}$. The detection system was a nonintensified CCD (Charge Coupled Device) and the entrance slit was set to $300 \mu \mathrm{m}$.

The $514.5 \mathrm{~nm}$ line of an $\mathrm{Ar}^{+}$laser (Coherent, model Innova 300) was used as excitation radiation, providing $100-120 \mathrm{~mW}$ at the sample position. Samples were sealed in Kimax glass capillary tubes of $0.8 \mathrm{~mm}$ inner diameter. Under the abovementioned conditions, the error in wavenumbers was estimated to be within $1 \mathrm{~cm}^{-1}$.

2.3. Ab Initio MO Calculations. The ab initio calculations were carried out with the GAUSSIAN $98 \mathrm{~W}$ program, ${ }^{25}$ within the density functional theory (DFT) approach, using the B3LYP
TABLE 3: Experimental and Calculated Wavenumbers $\left(\mathrm{cm}^{-1}\right)$ for 1,4-Diaminobutane (Putrescine) $\left(C_{2 h}\right)$ in the Low-Frequency Region

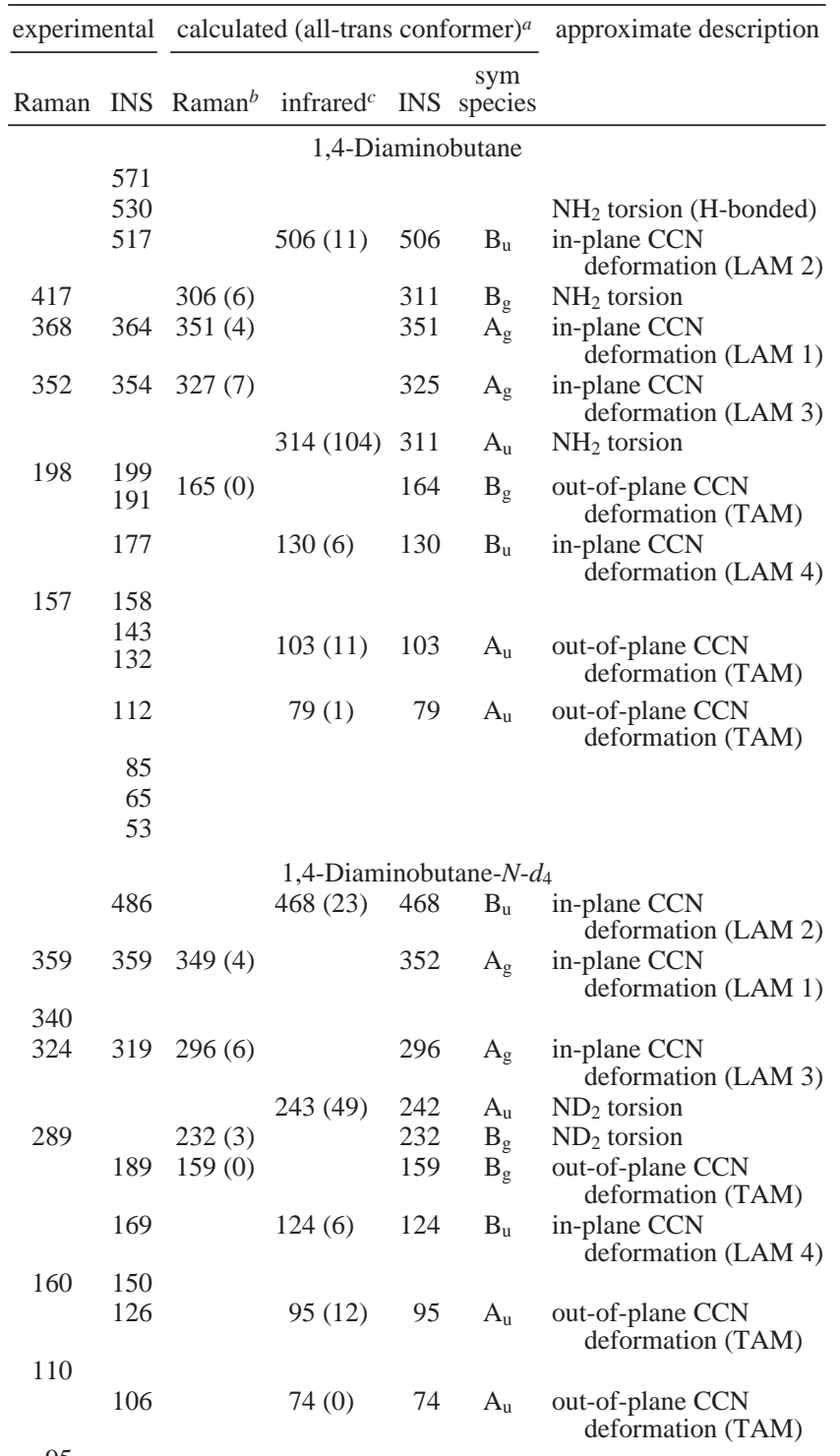

95

$$
\begin{aligned}
& 81 \\
& 63 \\
& 51
\end{aligned}
$$

${ }^{a}$ B3LYP/6-31G* level of calculation. ${ }^{b}$ Raman scattering activities in $\AA \cdot \mathrm{amu}^{-1}$. ${ }^{c}$ IR intensities in $\mathrm{km} \cdot \mathrm{mol}^{-1}$.

method, ${ }^{26-31}$ which includes a mixture of Hartree-Fock (HF) and DFT exchange terms. The gradient-corrected correlation functional was used ${ }^{32,33}$ (parametrized after Becke ${ }^{34,35}$ ), along with the double- $\zeta$ split valence basis sets $6-31 \mathrm{G}^{* 36}$ and 6-31G**.36,37

Only the geometries with all skeletal dihedral angles equal to $180^{\circ}$ (all-trans) were considered in the present work. Molecular geometries were fully optimized by the Berny algorithm, using redundant internal coordinates: ${ }^{38}$ the bond lengths to within ca. $0.1 \mathrm{pm}$ and the bond angles to within ca. $0.1^{\circ}$. The final root-mean-square (rms) gradients were always less than $3 \times 10^{-4}$ Hartree $\cdot$ bohr $^{-1}$ or Hartree $\cdot$ radian $^{-1}$.

The calculated INS transition intensities were obtained as previously reported, ${ }^{23}$ using a program written by Chris Middleton, of Syracuse University, Syracuse, NY. The bandwidths of the calculated spectra were adjusted by inspection, on a sample by sample basis, to provide the best agreement with the experimental data. 
TABLE 4: Experimental and Calculated Wavenumbers $\left(\mathrm{cm}^{-1}\right)$ for 1,5-Diaminopentane (Cadaverine) $\left(C_{2 v}\right)$ in the Low-Frequency Region

\begin{tabular}{|c|c|c|c|c|c|c|}
\hline \multicolumn{2}{|c|}{ xperimental } & \multicolumn{4}{|c|}{ calculated (all-trans conformer) $^{a}$} & \multirow[t]{2}{*}{ approximate description } \\
\hline Raman & INS & $\operatorname{Raman}^{b}$ & infrared $^{c}$ & \multicolumn{2}{|c|}{$\begin{array}{c}\text { sym } \\
\text { INS }\end{array}$} & \\
\hline \multicolumn{7}{|c|}{ 1,5-Diaminopentane } \\
\hline & $\begin{array}{l}530 \\
504\end{array}$ & & $501(3)$ & 501 & $\mathrm{~B}_{2}$ & $\begin{array}{l}\mathrm{NH}_{2} \text { torsion }(\mathrm{H} \text {-bonded }) \\
\text { in-plane } \mathrm{CCN} \text { deformation } \\
\quad(\mathrm{LAM} 2)\end{array}$ \\
\hline 460 & 454 & $443(1)$ & $443(4)$ & 443 & $\mathrm{~A}_{1}$ & $\begin{array}{l}\text { in-plane CCN deformation } \\
\text { (LAM 3) }\end{array}$ \\
\hline 418 & & $301(1)$ & 301 (105) & 300 & $\mathrm{~B}_{1}$ & $\mathrm{NH}_{2}$ torsion \\
\hline 418 & & $300(5)$ & & 300 & $\mathrm{~A}_{2}$ & $\mathrm{NH}_{2}$ torsion \\
\hline 326 & 315 & $301(10)$ & & 300 & $\mathrm{~A}_{1}$ & $\begin{array}{l}\text { in-plane CCN deformation } \\
\text { (LAM 1) }\end{array}$ \\
\hline 313 & 290 & & $255(7)$ & 255 & $\mathrm{~B}_{2}$ & $\begin{array}{l}\text { in-plane CCN deformation } \\
\text { (LAM 4) }\end{array}$ \\
\hline 183 & 189 & & $162(3)$ & 162 & $\mathrm{~B}_{1}$ & $\begin{array}{l}\text { out-of-plane CCN } \\
\text { deformation (TAM) }\end{array}$ \\
\hline \multirow[t]{3}{*}{177} & 167 & $149(0)$ & $149(0)$ & 150 & $\mathrm{~A}_{2}$ & $\begin{array}{l}\text { out-of-plane CCN } \\
\text { deformation (TAM) }\end{array}$ \\
\hline & 144 & & $99(2)$ & 99 & $\mathrm{~A}_{1}$ & $\begin{array}{l}\text { in-plane CCN deformation } \\
\text { (LAM 5) }\end{array}$ \\
\hline & 134 & $89(0)$ & $89(0)$ & 89 & $\mathrm{~A}_{2}$ & $\begin{array}{l}\text { out-of-plane CCN } \\
\text { deformation (TAM) }\end{array}$ \\
\hline 108 & 111 & & $68(3)$ & 68 & $\mathrm{~B}_{1}$ & $\begin{array}{l}\text { out-of-plane CCN } \\
\text { deformation (TAM) }\end{array}$ \\
\hline \multirow[t]{4}{*}{102} & 99 & & & & & \\
\hline & 89 & & & & & \\
\hline & 75 & & & & & \\
\hline & 48 & & & & & \\
\hline \multicolumn{7}{|c|}{ 1,5-Diaminopentane- $N$ - $d_{4}$} \\
\hline \multirow[t]{2}{*}{477} & 483 & & $474(11)$ & 474 & $\mathrm{~B}_{2}$ & $\begin{array}{l}\text { in-plane CCN deformation } \\
\text { (LAM 2) }\end{array}$ \\
\hline & 438 & $422(1)$ & $422(3)$ & 422 & $\mathrm{~A}_{1}$ & $\begin{array}{l}\text { in-plane CCN deformation } \\
\text { (LAM 3) }\end{array}$ \\
\hline \multirow[t]{5}{*}{320} & 301 & $287(9)$ & & 287 & $\mathrm{~A}_{1}$ & $\begin{array}{l}\text { in-plane CCN deformation } \\
\text { (LAM 1) }\end{array}$ \\
\hline & 278 & & $243(9)$ & 242 & $\mathrm{~B}_{2}$ & $\begin{array}{l}\text { in-plane CCN deformation } \\
\text { (LAM 4) }\end{array}$ \\
\hline & & & $233(49)$ & 232 & $\mathrm{~B}_{1}$ & $\mathrm{ND}_{2}$ torsion \\
\hline & & $231(2)$ & & 232 & $\mathrm{~A}_{2}$ & $\mathrm{ND}_{2}$ torsion \\
\hline & & & $154(5)$ & 153 & $\mathrm{~B}_{1}$ & $\begin{array}{l}\text { out-of-plane CCN } \\
\text { deformation (TAM) }\end{array}$ \\
\hline \multirow[t]{2}{*}{179} & 183 & $146(0)$ & $146(0)$ & 147 & $\mathrm{~A}_{2}$ & $\begin{array}{l}\text { out-of-plane CCN } \\
\text { deformation (TAM) }\end{array}$ \\
\hline & 142 & & 95 (2) & 95 & $\mathrm{~A}_{1}$ & $\begin{array}{l}\text { in-plane CCN deformatic } \\
\text { (LAM 5) }\end{array}$ \\
\hline \multirow{4}{*}{$\begin{array}{l}107 \\
102\end{array}$} & 110 & & & & & \\
\hline & & $80(0)$ & 80 & 80 & & \\
\hline & 88 & $80(0)$ & $80(0)$ & 80 & $A_{2}$ & deformation (TAM) \\
\hline & 72 & & $66(3)$ & 66 & $\mathrm{~B}_{1}$ & $\begin{array}{l}\text { out-of-plane CCN } \\
\text { deformation (TAM) }\end{array}$ \\
\hline
\end{tabular}

${ }^{a} \mathrm{~B} 3 \mathrm{LYP} / 6-31 \mathrm{G}^{*}$ level of calculation. ${ }^{b}$ Raman scattering activities in $\AA \cdot \mathrm{amu}^{-1}$. ${ }^{c}$ IR intensities in $\mathrm{km} \cdot \mathrm{mol}^{-1}$.

2.4. Reagents. The polyamines were purchased from SigmaAldrich. The deuterated compounds were obtained by mixing the amines with $\mathrm{D}_{2} \mathrm{O}$ (ca. $10 \%$ excess) and distilling under vacuum (this process being repeated at least three times). The solid amines were purified by sublimation, while the liquids were distilled under vacuum. All the samples being air or moisture sensitive, they were always handled in a glovebox under an argon atmosphere.

\section{Results and Discussion}

This kind of linear polyamine molecules can adopt different conformations, by varying the dihedral angles that determine their overall orientation. The most common geometries have skeletal dihedral angles near $60^{\circ}$ (gauche), $180^{\circ}$ (trans), and $-60^{\circ}$ (gauche'). Intramolecular $(\mathrm{N}) \mathrm{H} \cdots: \mathrm{N}$ and $(\mathrm{C}) \mathrm{H} \cdots: \mathrm{N}$ hydrogen bonds determine the conformational preferences of these compounds, as previously confirmed by both ab initio methods
TABLE 5: Experimental and Calculated Wavenumbers $\left(\mathrm{cm}^{-1}\right)$ for Spermidine $\left(C_{1}\right)$ in the Low-Frequency Region.

\begin{tabular}{|c|c|c|c|c|c|}
\hline \multicolumn{2}{|c|}{ experimental } & \multicolumn{3}{|c|}{$\begin{array}{c}\text { calculated } \\
\left(\text { all-trans conformer) }{ }^{a}\right.\end{array}$} & \multirow[t]{2}{*}{ approximate description } \\
\hline Raman & INS & $\operatorname{Raman}^{b}$ & infrared $^{c}$ & INS & \\
\hline \multirow{3}{*}{526} & & \multirow{3}{*}{$529(2)$} & \multicolumn{2}{|c|}{ Spermidine } & \\
\hline & 529 & & $529(1)$ & 529 & $\begin{array}{l}\text { in-plane CCN deformation } \\
\text { (LAM 3) }\end{array}$ \\
\hline & 513 & & $507(3)$ & 507 & $\begin{array}{l}\text { in-plane CCN deformation } \\
\text { (LAM 4) }\end{array}$ \\
\hline 408 & 414 & & $407(2)$ & 407 & $\begin{array}{l}\text { in-plane CCN deformation } \\
\text { (LAM 2) }\end{array}$ \\
\hline 382 & 400 & $385(1)$ & $385(1)$ & 385 & $\begin{array}{l}\text { in-plane CCN deformation } \\
\text { (LAM 5) }\end{array}$ \\
\hline \multirow{3}{*}{$\sim 370$} & & $304(2)$ & $304(59)$ & 302 & $\mathrm{NH}_{2}$ torsion \\
\hline & & $301(3)$ & 301 (44) & 302 & $\mathrm{NH}_{2}$ torsion \\
\hline & 277 & & $252(10)$ & 252 & $\begin{array}{l}\text { in-plane CCN deformation } \\
\text { (LAM 6) }\end{array}$ \\
\hline \multirow[t]{2}{*}{240} & 246 & $228(8)$ & & 228 & $\begin{array}{l}\text { in-plane CCN deformation } \\
\text { (LAM 1) }\end{array}$ \\
\hline & 211 & & $179(2)$ & 179 & $\begin{array}{l}\text { out-of-plane CCN deformation } \\
\text { (TAM) }\end{array}$ \\
\hline 197 & 198 & & $165(5)$ & 165 & $\begin{array}{l}\text { out-of-plane CCN deformation } \\
\text { (TAM) }\end{array}$ \\
\hline \multirow[t]{2}{*}{181} & 183 & & $139(2)$ & 138 & $\begin{array}{l}\text { out-of-plane CCN deformation } \\
\text { (TAM) }\end{array}$ \\
\hline & $\sim 168$ & $137(1)$ & & 138 & $\begin{array}{l}\text { in-plane CCN deformation } \\
\text { (LAM 7) }\end{array}$ \\
\hline 149 & 146 & & $116(1)$ & 116 & $\begin{array}{l}\text { out-of-plane CCN deformation } \\
\text { (TAM) }\end{array}$ \\
\hline $\begin{array}{l}131 \\
122\end{array}$ & & $86(0)$ & $86(0)$ & 85 & $\begin{array}{l}\text { out-of-plane CCN deformation } \\
\text { (TAM) }\end{array}$ \\
\hline \multirow[t]{4}{*}{111} & 110 & & $66(6)$ & 66 & $\begin{array}{l}\text { out-of-plane CCN deformation } \\
\text { (TAM) }\end{array}$ \\
\hline & 97 & & $52(1)$ & 52 & $\begin{array}{l}\text { in-plane CCN deformation } \\
\text { (LAM 8) }\end{array}$ \\
\hline & 88 & $35(0)$ & $35(0)$ & 35 & $\begin{array}{l}\text { out-of-plane CCN deformation } \\
\text { (TAM) }\end{array}$ \\
\hline & $\begin{array}{l}70 \\
57 \\
50\end{array}$ & & & & \\
\hline \multirow{3}{*}{509} & & & Spermi & dine- $N$ & $-d_{5}$ \\
\hline & 511 & $510(1)$ & $510(1)$ & 510 & $\begin{array}{l}\text { in-plane CCN deformation } \\
\text { (LAM 3) }\end{array}$ \\
\hline & 494 & & $489(7)$ & 489 & $\begin{array}{l}\text { in-plane CCN deformation } \\
\text { (LAM 4) }\end{array}$ \\
\hline \multirow[t]{2}{*}{397} & 395 & & $388(5)$ & 388 & $\begin{array}{l}\text { in-plane CCN deformation } \\
\text { (LAM 2) }\end{array}$ \\
\hline & 382 & $369(1)$ & $369(1)$ & 369 & $\begin{array}{l}\text { in-plane CCN deformation } \\
\text { (LAM 5) }\end{array}$ \\
\hline 285 & & $234(1)$ & $234(36)$ & 233 & $\mathrm{ND}_{2}$ torsion \\
\hline 274 & 267 & & $243(11)$ & 242 & $\begin{array}{l}\text { in-plane CCN deformation } \\
\text { (LAM 6) }\end{array}$ \\
\hline \multirow[t]{2}{*}{233} & 239 & $222(8)$ & $222(1)$ & 223 & $\begin{array}{l}\text { in-plane CCN deformation } \\
\text { (LAM 1) }\end{array}$ \\
\hline & 205 & & $174(1)$ & 174 & $\begin{array}{l}\text { out-of-plane CCN deformation } \\
\text { (TAM) }\end{array}$ \\
\hline 190 & 190 & & 159 (7) & 159 & $\begin{array}{l}\text { out-of-plane CCN deformation } \\
\text { (TAM) }\end{array}$ \\
\hline \multirow[t]{2}{*}{177} & 172 & & $135(2)$ & 134 & $\begin{array}{l}\text { out-of-plane CCN deformation } \\
\text { (TAM) }\end{array}$ \\
\hline & 163 & $132(1)$ & & 134 & $\begin{array}{l}\text { in-plane CCN deformation } \\
\text { (LAM 7) }\end{array}$ \\
\hline 148 & 143 & & $108(1)$ & 108 & $\begin{array}{l}\text { out-of-plane CCN deformation } \\
\text { (TAM) }\end{array}$ \\
\hline $\begin{array}{l}130 \\
121\end{array}$ & & $83(0)$ & $83(0)$ & 83 & $\begin{array}{l}\text { out-of-plane CCN deformation } \\
\text { (TAM) }\end{array}$ \\
\hline 110 & 108 & & $61(6)$ & 61 & $\begin{array}{l}\text { out-of-plane CCN deformation } \\
\text { (TAM) }\end{array}$ \\
\hline \multirow[t]{3}{*}{92} & 94 & & $50(1)$ & 50 & $\begin{array}{l}\text { in-plane CCN deformation } \\
\text { (LAM 8) }\end{array}$ \\
\hline & 86 & & $33(0)$ & 33 & $\begin{array}{l}\text { out-of-plane CCN deformation } \\
\text { (TAM) }\end{array}$ \\
\hline & $\begin{array}{l}69 \\
56 \\
49\end{array}$ & & & & \\
\hline
\end{tabular}

${ }^{a}$ B3LYP/6-31G* level of calculation. ${ }^{b}$ Raman scattering activities in $\AA \cdot a u^{-1}$. ${ }^{c}$ IR intensities in $\mathrm{km} \cdot \mathrm{mol}^{-1}$.

and Raman spectroscopy for molecules as liquids and aqueous solutes. ${ }^{19-21}$ However, the crystal packing of the polyamines in the solid state, which corresponds to the present study, is 
TABLE 6: Experimental and Calculated Wavenumbers $\left(\mathrm{cm}^{-1}\right)$ for Spermine $\left(C_{2}\right)$ in the Low-Frequency Region

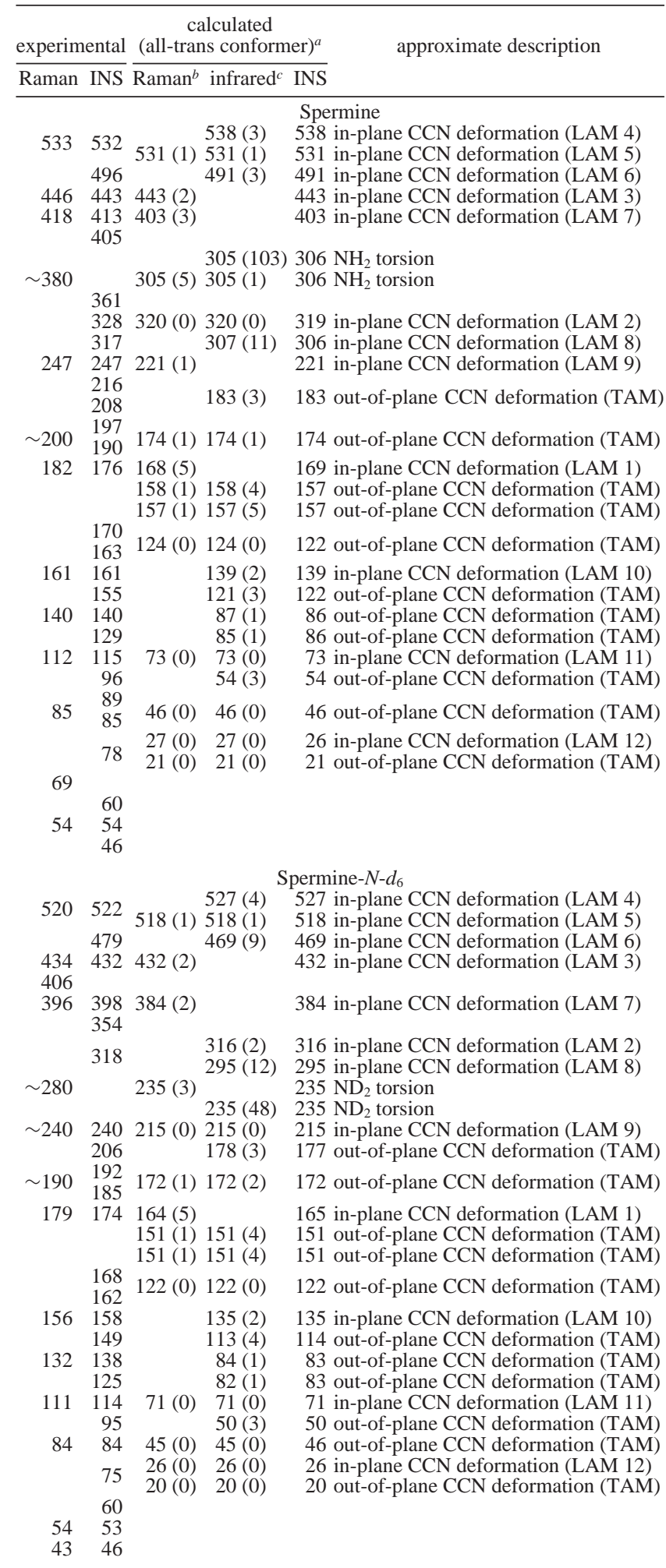

${ }^{a} \mathrm{~B} 3 \mathrm{LYP} / 6-31 \mathrm{G}^{*}$ level of calculation. ${ }^{b}$ Raman scattering activities in $\AA \cdot \mathrm{amu}^{-1}$. ${ }^{c}$ IR intensities in $\mathrm{km} \cdot \mathrm{mol}^{-1}$.

not compatible with conformations displaying this kind of intramolecular close contacts. Thus, only the all-trans conformers (Figure 1) are expected to occur. Under these conditions the polyamines behave very much as saturated linear alkanes, for which the all-trans conformation has long been recognized as energetically the most favored. ${ }^{39}$ Moreover, at physiological $\mathrm{pH}$ these amines are totally protonated, which renders them into

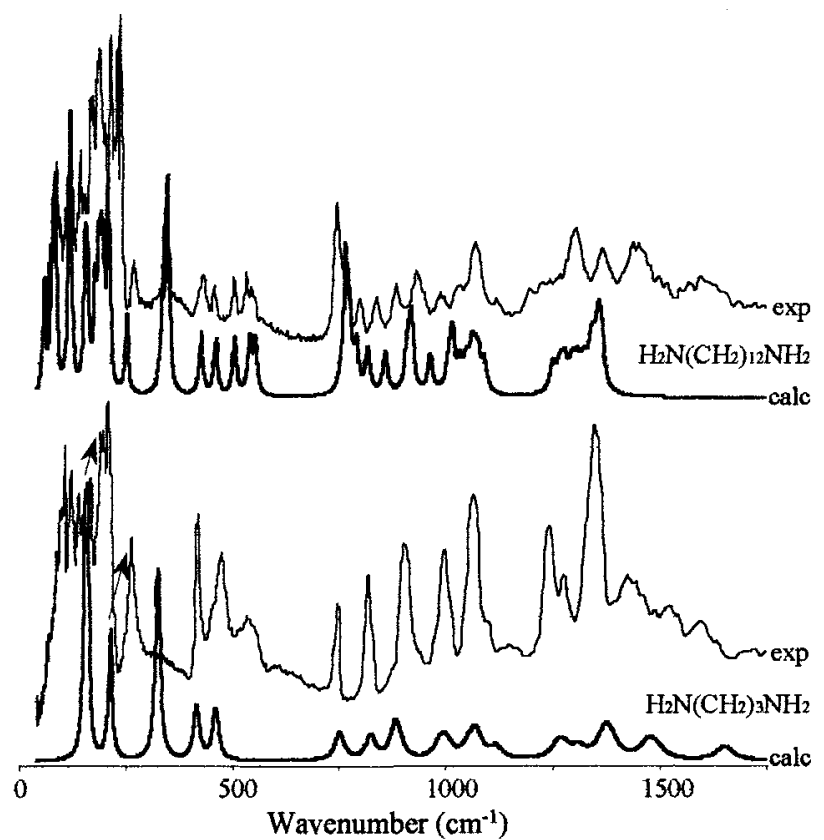

Figure 4. Experimental $(20 \mathrm{~K})$ and calculated (B3LYP/6-31G*) INS spectra $\left(16-1750 \mathrm{~cm}^{-1}\right)$ for two different $\mathrm{H}_{2} \mathrm{~N}_{(}\left(\mathrm{CH}_{2}\right)_{n} \mathrm{NH}_{2}$ diamines.

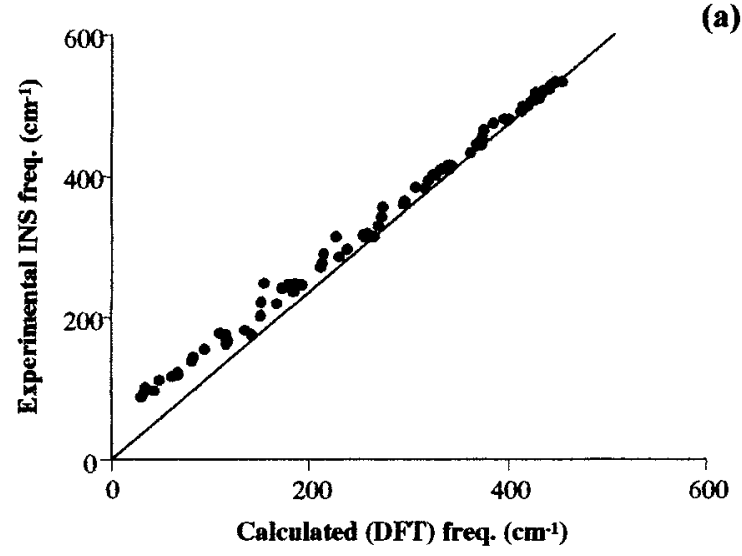

(a)

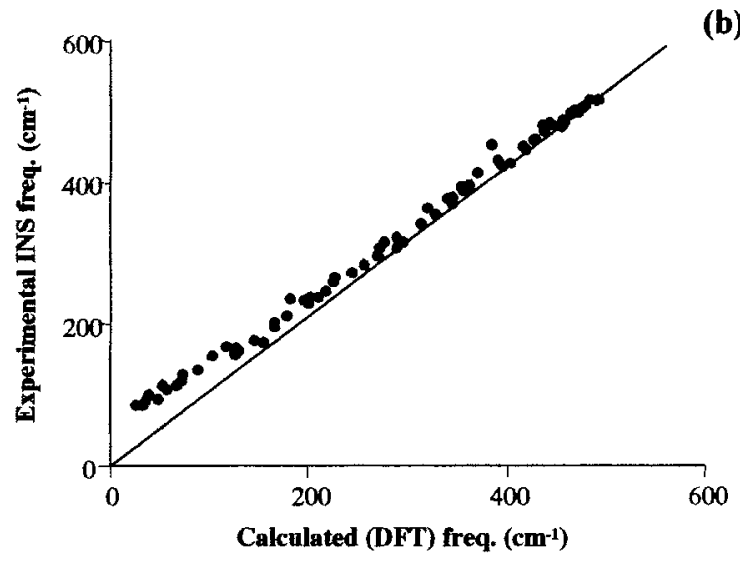

Figure 5. Plots of experimental vs calculated INS band center frequencies (LAM modes) for the series of polyamines studied $\left(\mathrm{H}_{2} \mathrm{~N}\left(\mathrm{CH}_{2}\right)_{n} \mathrm{NH}_{2}(n=2-10, n=12)\right.$, spermidine and spermine): (a) undeuterated; (b) N-deuterated. (Calculated values obtained at the B3LYP/6-31G* level. The lines correspond to a full accordance.)

polycationic species and hinders the formation of either $(\mathrm{N}) \mathrm{H} \cdots: \mathrm{N}$ or $(\mathrm{C}) \mathrm{H} \cdots: \mathrm{N}$ intramolecular contacts.

In the absence of intramolecular hydrogen-bond interactions in these totally extended amines, only three effects are relevant 
TABLE 7: Longitudinal Acoustic Vibrational Modes (LAM's) for the $\mathrm{H}_{2} \mathrm{~N}\left(\mathrm{CH}_{2}\right)_{n} \mathrm{NH}_{2}(n=2-10, n=12)$ Diamines, Spermidine and Spermine

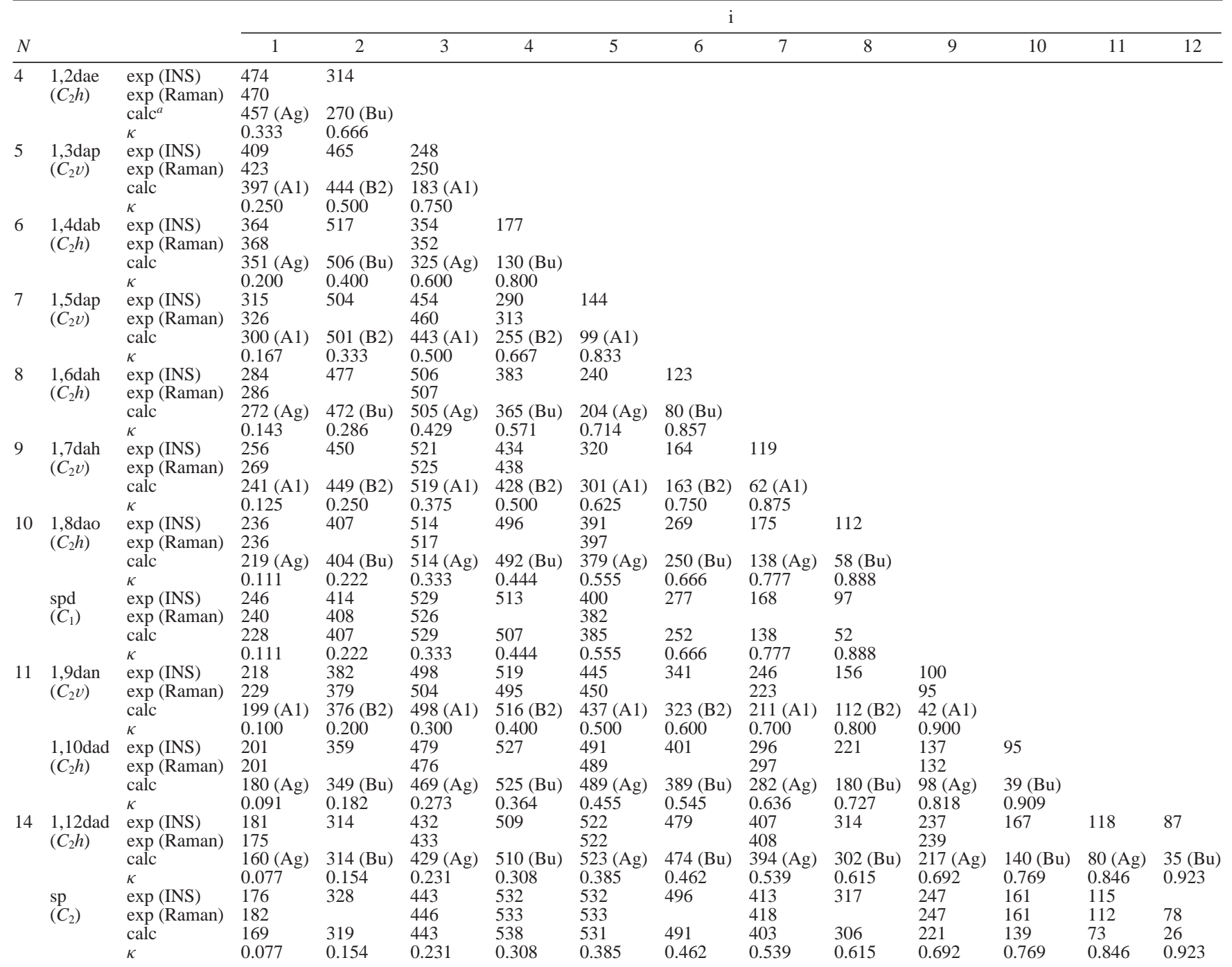

${ }^{a}$ At the B3LYP/6-31G* level. $i=1,2, \ldots,(N-2) ; \kappa=i /(N-1)$.

in determining conformation: intermolecular H-bonds and electrostatic and steric forces. The former are prone to be rather strong, given the linear geometry of our samples and the strong directional nature of the hydrogen bonds. ${ }^{40,41}$

Previously performed conformational studies on both small $\alpha, \omega$-diamines $\left(\mathrm{H}_{2} \mathrm{~N}\left(\mathrm{CH}_{2}\right)_{n} \mathrm{NH}_{2}, n=2-4\right)$ and similar linear polyamines $^{19-21}$ allowed us to corroborate that the all-trans is the predominant or even the sole conformation for this kind of molecules in the solid state. These conformational preferences also apply to the larger spermidine (triamine) and spermine (tetramine), despite the stronger possibility of formation of intramolecular $(\mathrm{N}) \mathrm{H} \cdots: \mathrm{N}$ and/or $(\mathrm{C}) \mathrm{H} \cdots: \mathrm{N}$ bonds in these systems. In fact, it was verified that, in the solid, intramolecular interactions are overruled by intermolecular ones. Thus, the DFT calculations, carried out in the present work in view of helping the assignment of the vibrational patterns of the polyamines, were performed only for their linear, all-trans configuration. The homologous series of diamines, $\mathrm{H}_{2} \mathrm{~N}\left(\mathrm{CH}_{2}\right)_{n} \mathrm{NH}_{2}$, exhibit $C_{2 h}$ symmetry for even values of $n$, while the molecules with $n=$ odd belong to the $C_{2 v}$ symmetry point group. Spermidine and spermine, in turn, display a much lower symmetry $\left(C_{1}\right.$ and $C_{2}$, respectively). Both total geometry optimization and calculation of the harmonic vibrational frequencies and intensities were undertaken for the normal and the N-deuterated species (tables available from the authors upon request). The $6-31 \mathrm{G}^{*}$ basis set was used systematically, after verifying that consideration of polarization functions on the hydrogen atoms did not pay for the 3 -fold increase in computational requirements. As was seen in previous studies on similar systems, ${ }^{20}$ DFT calculations carried out at the B3LYP/6-31G* level display a good correlation with the MP2/6-31G** results.

Both INS and Raman experiments were conducted on samples in the solid state. Deuteration of the samples saw the observation of the anticipated shifts to lower frequencies (in both INS and Raman) as well as the loss of some INS intensity for the bands assigned to the vibrational modes of the $\mathrm{ND}_{2}$ group, as a consequence of the variations in both mass (frequencies) and scattering cross-section (INS intensities). In the INS spectra, this is clearly observed for the bands at ca. $1370 \mathrm{vs} 1000 \mathrm{~cm}^{-1}$ $\left(\mathrm{NH}_{2} / \mathrm{ND}_{2}\right.$ twisting modes) and at ca. $950 \mathrm{vs} 730 \mathrm{~cm}^{-1}\left(\mathrm{NH}_{2} /\right.$ $\mathrm{ND}_{2}$ wagging) (Figure 2). The most characteristic changes in the Raman pattern, in turn, are detected, as expected, for the amine torsional (ca. 390 vs $280 \mathrm{~cm}^{-1}$ ), scissoring (ca. 1650 vs $1200 \mathrm{~cm}^{-1}$ ), and stretching (ca. 3300 vs $2400 \mathrm{~cm}^{-1}$, Figure 3) bands. Also, a wavenumber shift to lower energies is found (in both Raman and INS), in agreement with the theoretical results, for some of the LAM modes: those associated with a significant change in the CCN angle (Tables 1-6, Tables IS-VIS). In the 
TABLE 8: LAM's for the Deuterated $\mathrm{D}_{2} \mathrm{~N}\left(\mathrm{CH}_{2}\right)_{n} \mathrm{ND}_{2}(n=2-10, n=12)$ Diamines, Spermidine- $N-d_{5}$ and Spermine- $N-d_{6}$

\begin{tabular}{|c|c|c|c|c|c|c|c|c|c|c|c|c|c|c|}
\hline \multirow{2}{*}{$N$} & & & \multicolumn{12}{|c|}{$i$} \\
\hline & & & 1 & 2 & 3 & 4 & 5 & 6 & 7 & 8 & 9 & 10 & 11 & 12 \\
\hline \multirow[t]{3}{*}{4} & 1,2dae & $\exp ($ INS) & 439 & 317 & & & & & & & & & & \\
\hline & $\left(C_{2 h}\right)$ & $\exp ($ Raman $)$ & $\begin{array}{l}436 \\
411(\mathrm{Ag})\end{array}$ & 249 (Ви) & & & & & & & & & & \\
\hline & & $\begin{array}{l}\mathrm{calc}^{a} \\
\kappa\end{array}$ & $\begin{array}{l}411(\mathrm{Ag}) \\
0.333\end{array}$ & $\begin{array}{l}249(\mathrm{Bu}) \\
0.666\end{array}$ & & & & & & & & & & \\
\hline \multirow{4}{*}{5} & 1,3dap & $\exp (\mathrm{INS})$ & 406 & 428 & & & & & & & & & & \\
\hline & $\left(C_{2 v}\right)$ & exp (Raman) & 411 & 411 & 235 & & & & & & & & & \\
\hline & & calc & 375 (A1) & 405 (B2) & 171 (A1) & & & & & & & & & \\
\hline & & $\kappa$ & 0.250 & 0.500 & 0.750 & & & & & & & & & \\
\hline \multirow[t]{4}{*}{6} & $1,4 \mathrm{dab}$ & $\exp (\mathrm{INS})$ & 359 & 486 & 319 & 169 & & & & & & & & \\
\hline & $\left(C_{2 h}\right)$ & $\exp ($ Raman) & 359 & & 324 & & & & & & & & & \\
\hline & & calc & $352(\mathrm{Ag})$ & $468(\mathrm{Bu})$ & $296(\mathrm{Ag})$ & $124(\mathrm{Bu})$ & & & & & & & & \\
\hline & & $\kappa$ & 0.200 & 0.400 & 0.600 & 0.800 & & & & & & & & \\
\hline \multirow[t]{3}{*}{7} & 1,5dap & $\begin{array}{l}\exp \text { (INS) } \\
\text { exn (Raman) }\end{array}$ & $\begin{array}{l}301 \\
320\end{array}$ & $\begin{array}{l}483 \\
477\end{array}$ & 438 & 278 & 142 & & & & & & & \\
\hline & & $\begin{array}{l}\text { exp (Kaman) } \\
\text { calc }\end{array}$ & 287 (A1) & 474 (B2) & 422 (A1) & 242 (B2) & $95(\mathrm{~A} 1)$ & & & & & & & \\
\hline & & $\kappa$ & 0.167 & 0.333 & 0.500 & 0.667 & 0.833 & & & & & & & \\
\hline \multirow[t]{3}{*}{8} & $\begin{array}{l}1,6 \mathrm{dah} \\
\left(C_{2 h}\right)\end{array}$ & $\begin{array}{l}\exp (\text { INS) } \\
\exp (\text { Raman) }\end{array}$ & $\begin{array}{l}274 \\
272\end{array}$ & 467 & $\begin{array}{l}487 \\
491\end{array}$ & 368 & 237 & 128 & & & & & & \\
\hline & & calc & $261(\mathrm{Ag})$ & $458(\mathrm{Bu})$ & $477(\mathrm{Ag})$ & $343(\mathrm{Bu})$ & $193(\mathrm{Ag})$ & $77(\mathrm{Bu})$ & & & & & & \\
\hline & & $\kappa$ & 0.143 & 0.286 & $0.429^{\circ}$ & 0.571 & 0.714 & 0.857 & & & & & & \\
\hline \multirow[t]{4}{*}{9} & $1,7 \mathrm{dah}$ & $\exp (\mathrm{INS})$ & 249 & 452 & 503 & 419 & 311 & & 107 & & & & & \\
\hline & $\left(C_{2 v}\right)$ & $\exp ($ Raman $)$ & 255 & & & 415 & 306 & & & & & & & \\
\hline & & calc & 232 (A1) & 449 (B2) & 497 (A1) & 397 (B2) & 290 (A1) & 160 (B2) & $60(\mathrm{~A} 1)$ & & & & & \\
\hline & & $\kappa$ & 0.125 & 0.250 & 0.375 & 0.500 & 0.625 & 0.750 & 0.875 & & & & & \\
\hline \multirow[t]{7}{*}{10} & 1,8 dao & $\exp ($ INS) & 231 & 401 & 504 & 487 & 381 & 262 & 167 & 112 & & & & \\
\hline & $\left(C_{2 h}\right)$ & exp (Raman) & 229 & & 500 & & 388 & & & & & & & \\
\hline & & $\begin{array}{l}\text { calc } \\
\kappa\end{array}$ & $\begin{array}{l}213(\mathrm{Ag}) \\
0.111\end{array}$ & $\begin{array}{l}389(\mathrm{Bu}) \\
0.222\end{array}$ & $\begin{array}{l}497(\mathrm{Ag}) \\
0.333\end{array}$ & $\begin{array}{l}4 / 8(\mathrm{Bu}) \\
0.444\end{array}$ & $\begin{array}{l}365(\mathrm{Ag}) \\
0.555\end{array}$ & $\begin{array}{l}241(\mathrm{Bu}) \\
0.666\end{array}$ & $\begin{array}{l}134(\mathrm{Ag}) \\
0.777\end{array}$ & $\begin{array}{l}55(\mathrm{Bu}) \\
0.888\end{array}$ & & & & \\
\hline & spd & $\exp (\mathrm{INS})$ & 239 & 395 & 511 & 494 & 382 & 267 & 163 & & & & & \\
\hline & $\left(\mathrm{C}_{1}\right)$ & $\exp ($ Raman) & 233 & 397 & 509 & & & 274 & & & & & & \\
\hline & & calc & 223 & 388 & 510 & 489 & 369 & 242 & 134 & & & & & \\
\hline & & $\kappa$ & 0.111 & 0.222 & 0.333 & 0.444 & 0.555 & 0.666 & 0.777 & 0.888 & & & & \\
\hline \multirow[t]{4}{*}{11} & 1,9dan & $\exp (\mathrm{INS})$ & 213 & 375 & 491 & 506 & 436 & 325 & 235 & 154 & 99 & & & \\
\hline & $(C)$, & $\exp ($ Raman $)$ & 227 & 373 & 494 & 510 & 42 & & 213 & & 93 & & & \\
\hline & & calc & 190 (A1) & 369 (B2) & 491 (A1) & 500 (B2) & 418 (A1) & 310 (B2) & 209 (A1) & 109 (B2) & $41(\mathrm{~A} 1)$ & & & \\
\hline & & $\kappa$ & 0.100 & 0.200 & 0.300 & 0.400 & 0.500 & 0.600 & 0.700 & 0.800 & 0.900 & & & \\
\hline \multirow[t]{3}{*}{12} & $\begin{array}{l}1,10 \mathrm{dad} \\
\left(C_{2 h}\right)\end{array}$ & $\begin{array}{l}\exp (\text { INS) } \\
\exp (\text { Raman) }\end{array}$ & $\begin{array}{l}198 \\
197\end{array}$ & 345 & $\begin{array}{l}456 \\
453\end{array}$ & 512 & $\begin{array}{l}485 \\
487\end{array}$ & 392 & $\begin{array}{l}286 \\
287\end{array}$ & 203 & $\begin{array}{l}135 \\
132\end{array}$ & 90 & & \\
\hline & & calc & $177(\mathrm{Ag})$ & $336(\mathrm{Bu})$ & $445(\mathrm{Ag})$ & $511(\mathrm{Bu})$ & $488(\mathrm{Ag})$ & $382(\mathrm{Bu})$ & $274(\mathrm{Ag})$ & $177(\mathrm{Bu})$ & $94(\mathrm{Ag})$ & $37(\mathrm{Bu})$ & & \\
\hline & & $\kappa$ & 0.091 & 0.182 & 0.273 & 0.364 & 0.455 & 0.545 & 0.636 & 0.727 & $0.818^{\circ}$ & 0.909 & & \\
\hline \multirow[t]{7}{*}{14} & $1,12 \mathrm{dad}$ & $\exp ($ INS) & 177 & 311 & 427 & 505 & 514 & 465 & 399 & 300 & 231 & 161 & 119 & 85 \\
\hline & $\left(C_{2 h}\right)$ & $\begin{array}{l}\exp (\text { Raman) } \\
\text { calc }\end{array}$ & 173 & & 427 & & 516 & & 400 & & 231 & & 123 & \\
\hline & & calc & $\begin{array}{l}155(\mathrm{Ag}) \\
0.077\end{array}$ & $\begin{array}{l}309(\mathrm{Bu}) \\
0154\end{array}$ & $\begin{array}{l}424(\mathrm{Ag}) \\
0231\end{array}$ & $506(\mathrm{Bu})$ & $513(\mathrm{Ag})$ & $\begin{array}{l}457(\mathrm{Bu}) \\
0.462\end{array}$ & $\begin{array}{l}380(\mathrm{Ag}) \\
0.539\end{array}$ & $\begin{array}{l}289(\mathrm{Bu}) \\
0.615\end{array}$ & $\begin{array}{l}213(\mathrm{Ag}) \\
0.692\end{array}$ & $137(\mathrm{Bu})$ & $\begin{array}{l}76(\mathrm{Ag}) \\
0846\end{array}$ & $\begin{array}{l}34(\mathrm{Bu}) \\
0.923\end{array}$ \\
\hline & $\mathrm{sp}$ & $\begin{array}{l}\kappa \\
\exp (\mathrm{INS})\end{array}$ & 174 & 318 & $\begin{array}{l}0.231 \\
432\end{array}$ & $\begin{array}{l}0.308 \\
522\end{array}$ & $\begin{array}{l}0.385 \\
522\end{array}$ & $\begin{array}{l}0.462 \\
479\end{array}$ & $\begin{array}{l}0.539 \\
398\end{array}$ & $\begin{array}{l}0.615 \\
318\end{array}$ & $\begin{array}{l}0.692 \\
240\end{array}$ & $\begin{array}{l}0.169 \\
158\end{array}$ & & 75 \\
\hline & $\left(\mathrm{C}_{2}\right)$ & $\exp$ (Raman) & 179 & & 434 & 520 & 520 & & 396 & & 240 & 15 & 111 & \\
\hline & & calc & 165 & 316 & 432 & 527 & 518 & 469 & 384 & 295 & 215 & 135 & & 26 \\
\hline & & $\kappa$ & 0.077 & 0.154 & 0.231 & 0.308 & 0.385 & 0.462 & 0.539 & 0.615 & 0.692 & 0.769 & 0.846 & 0.923 \\
\hline
\end{tabular}

${ }^{a}$ At the B3LYP/6-31G* level. $i=1,2, \ldots,(N-2) ; \kappa=i /(N-1)$.

case of 1,10-diaminodecane, for instance, LAM 5, which is hardly detected in the Raman spectrum (very weak band close to LAM 3), is clearly observed in the N-deuterated amine, due to this shift to lower frequencies displayed by LAM 3 upon deuteration (Table VS).

The agreement between the INS experimental and calculated spectra showed to be rather good above $250 \mathrm{~cm}^{-1}$ (Figures 4 and 5), with the exception of the torsional modes of the amine terminal groups (discussed below).

A complete assignment of the LAM's for the whole series of homologous amines under study (including their $\mathrm{N}$-deuterated forms) is given in Tables 7 and 8 . This was carried out by comparison with the ab initio results and the analogous data obtained for the 5-25 $n$-alkanes. ${ }^{23}$ It was verified that all the LAM's have the same INS intensity, their number increasing with chain length and the frequency of LAM 1 (accordion mode) being inversely proportional to this length (Tables 7 and 8, Figure 6).

The INS experimental LAM's observed for these polyamines are in good accordance with the LAM's of the corresponding $n$-alkanes ${ }^{23}$ (Figure 7), which supports the idea of a significant conformational similarity (in the solid state) between these two sets of compounds. In the $n$-alkanes the $\mathrm{CH}_{3}$ torsions appear as isolated and intense features around $250 \mathrm{~cm}^{-1}$ (e.g., Figure 7,

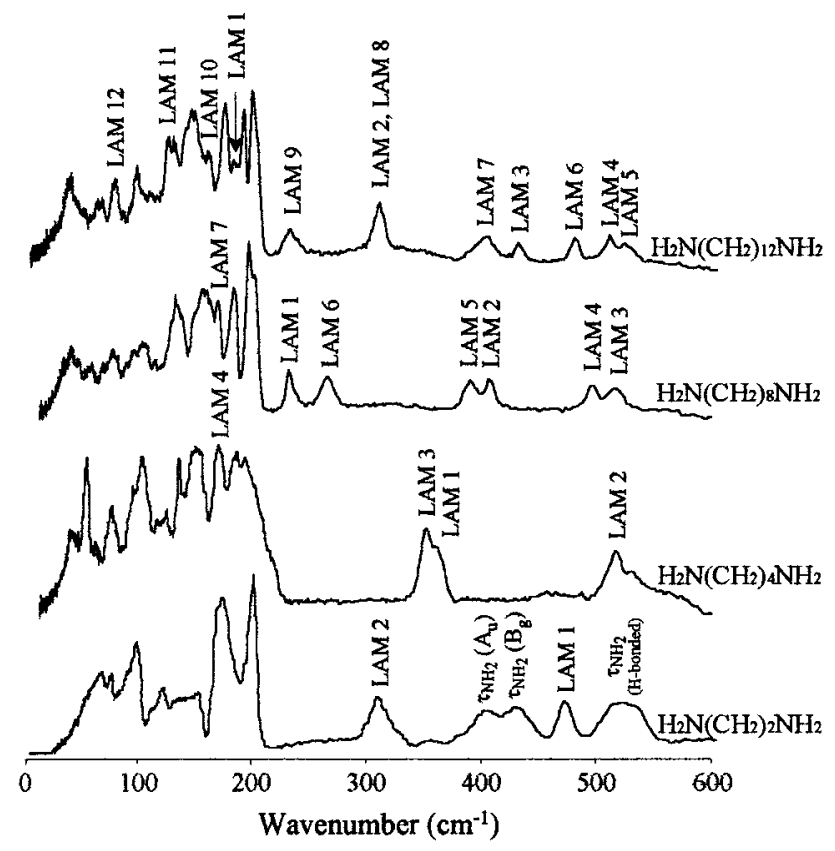

Figure 6. Experimental INS spectra $\left(16-600 \mathrm{~cm}^{-1}\right.$, at $\left.20 \mathrm{~K}\right)$ for some $\mathrm{H}_{2} \mathrm{~N}\left(\mathrm{CH}_{2}\right)_{n} \mathrm{NH}_{2}$ diamines. 


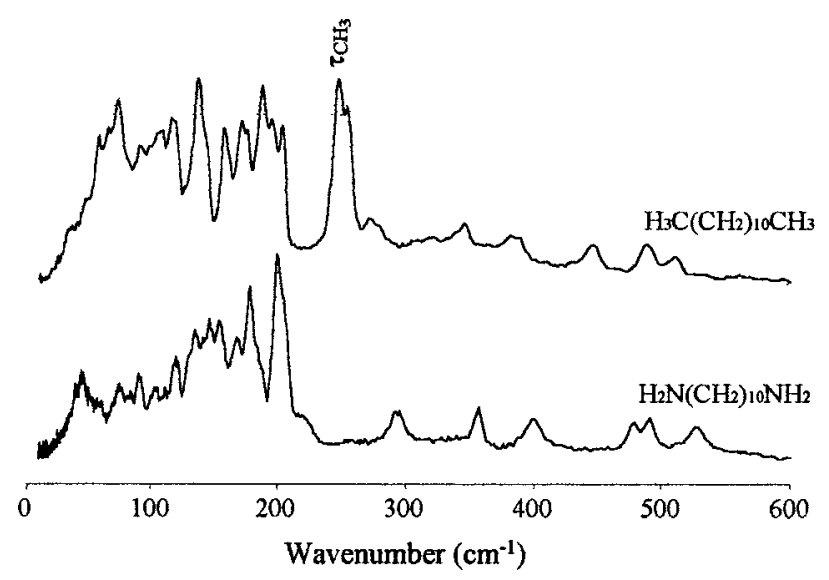

Figure 7. Experimental INS spectra $\left(16-600 \mathrm{~cm}^{-1}\right.$, at $\left.20 \mathrm{~K}\right)$ for a linear polyamine and the corresponding $n$-alkane. ${ }^{23}$

band at $247 \mathrm{~cm}^{-1}$ ). They are best described as vibrations involving most of the alkane backbone and description in terms of the torsions of isolated $\mathrm{CH}_{3}$ groups is inadequate. However, these vibrational modes obviously do not involve all of the $\mathrm{CH}_{n}$ units in the alkane; otherwise, the vibration would be part of the set of transverse modes in these systems, which appears below $200 \mathrm{~cm}^{-1}$. In turn, in the polyamines studied (except for 1,2-diaminoethane) the torsional mode of the amine terminal groups is not clearly observed above $210 \mathrm{~cm}^{-1}$, as would be expected from the theoretical calculations, which suggests that the occurrence of $\mathrm{R}-\mathrm{HN}-\mathrm{H} \cdots \mathrm{NH}_{2}-\mathrm{R}$ intermolecular interactions completely changes the nature of that vibration, from a chain mode to a localized torsion, restricted to the $\mathrm{NH}_{2}$ groups alone.

It should be stressed, however, that the nonobservation of the $\mathrm{NH}_{2}$ torsion modes in INS, for most of the polyamines studied in the present work, constitutes an unexpected result. A possible explanation for this is now put forward. The fact that 1,2-diaminoethane appears as an exception, as both $\tau_{\mathrm{NH}_{2}}$ $\mathrm{A}_{\mathrm{u}}\left(409 \mathrm{~cm}^{-1}\right)$ and $\mathrm{B}_{\mathrm{g}}\left(432 \mathrm{~cm}^{-1}\right)$ bands are distinctly detected (Figure 6) as well as a third band at $522 \mathrm{~cm}^{-1}$, is interpreted considering the presence of dimers in the solid for this small molecule. In fact, 1,2-diaminoethane having such a short alkylic chain between the two amine terminal groups will not be prone to form polymeric structures, due to an inefficient electronic charge delocalization through the carbon skeleton upon formation of intermolecular $\mathrm{H}_{2} \mathrm{~N} \cdots \mathrm{H}$ interactions simultaneously in both ends of the molecule, the dimeric species being the most favorable one in the solid state. The three distinct INS features are thus assigned to the hydrogen-bonded (central) $\mathrm{NH}_{2}$ groups $\left(522 \mathrm{~cm}^{-1}\right)$ and to the (terminal) $\mathrm{NH}_{2}$ moieties not engaged in intermolecular hydrogen close contacts (409 and $432 \mathrm{~cm}^{-1}$ ). While the nondegeneracy of the lowest energy $\tau_{\mathrm{NH}_{2}}$ modes is predicted, for this particular molecule alone, by the theoretical results ( $\Delta v$ of $39 \mathrm{~cm}^{-1}$, Table 1$)$, the band at higher frequency is not found by the calculations. In the case of 1,3-diaminopropane and the larger diamines now investigated, in turn, oligomeric forms are probable to occur in the condensed phase, both $\mathrm{NH}_{2}$ groups being thus involved in intermolecular hydrogen bonds, which would explain why only one band (H-bonded $\mathrm{NH}_{2}$ ) is detected in the INS spectra (at ca. $530 \mathrm{~cm}^{-1}$, for $\mathrm{H}_{2} \mathrm{~N}\left(\mathrm{CH}_{2}\right)_{n} \mathrm{NH}_{2} n=3-5$, Tables 2-4). As the chain lengthtens, a clear and progressive intensity decrease of this feature is observed, until it completely disappears, for 1,6-diaminohexane (Table IS), due to the smaller and smaller relative weight of the amine hydrogens in the molecule (Figure 6). This hypothesis is corroborated by INS results obtained for similar linear

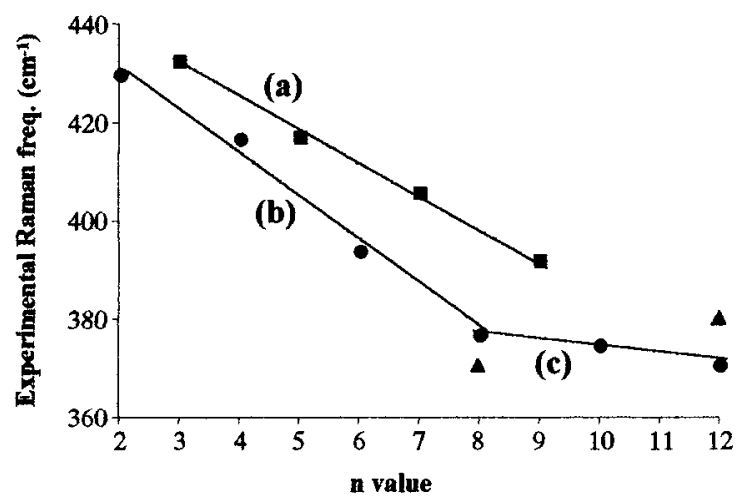

Figure 8. Plot of experimental Raman $\tau_{\mathrm{NH}_{2}}$ frequencies vs chain length, for the series of polyamines studied: even-membered (๑) and oddmembered (ם) $\mathrm{H}_{2} \mathrm{~N}\left(\mathrm{CH}_{2}\right)_{n} \mathrm{NH}_{2}$ diamines; spermidine and spermine $(\boldsymbol{\Delta})$.

monoamines, according to which a weak $\tau_{\mathrm{NH}_{2}}$ band is detected, for the shorter molecules only, at a frequency near to the one ascribed to the $\mathrm{H}_{2} \mathrm{~N} \cdots \mathrm{H}$ groups in the $\mathrm{H}_{2} \mathrm{~N}\left(\mathrm{CH}_{2}\right)_{n} \mathrm{NH}_{2}$ systems discussed above (e.g., $525 \mathrm{~cm}^{-1}$ for $n$-propylamine).

Through analysis of the Raman spectra of the whole series of molecules it was verified that $\tau_{\mathrm{NH}_{2}}$ displays a shift to lower frequencies as the polyamine increases, for the even- and oddmembered molecules, separately (Tables $1-6$, Tables IS-VIS, Figure 8). This variation of the torsional oscillations of the chain can be explained by a loosening effect as it gets longer, which is clearly more significant for an increase in chain length from $n=2$ to $n=9$ (Figure 8, lines a and b). In fact, for the larger molecules studied, the shift to lower energies detected in the Raman spectra is much smaller (Figure 8, line c). This can be explained by the occurrence of intermolecular $\mathrm{R}-\mathrm{HN}-\mathrm{H} \cdot \cdots$ $\mathrm{NH}_{2}-\mathrm{R}$ close contacts at the terminal $\mathrm{NH}_{2}$ groups of the chain. This type of interaction is present in some crystals, ${ }^{42,43}$ one amine donating a proton to a neighbor and in turn accepting another proton from a third molecule. Actually, a clear shift of $\tau_{\mathrm{NH}_{2}}$ to higher wavenumbers, when going from the liquid to the solid state, was previously observed in small primary amines $^{19,44}$ (e.g., 341 to $430 \mathrm{~cm}^{-1}$ for 1,2-diaminoethane ${ }^{19}$ ). This vibrational mode is, in fact, highly sensitive to intermolecular interactions, which are strongly dependent on the physical state of the sample, varying in the order: gas (isolated molecule) $\ll$ liquid $<$ solid. Also, it was now verified that this shift to higher energies decreases considerably as the polyamine chain lengthens (as described above), due to a weakening of the top-to-top close contacts between neighboring molecules as the number of carbons increase. The observed $n$-even $/ n$-odd dependence of the $\tau_{\mathrm{NH}_{2}}$ mode (Figure 8, lines a and b) may, in turn, be due to changes in their crystal structure with the parity of the molecules, similarly to what has been previously recognized for $n$ alkanes ${ }^{45,46}$ (namely the tighter packing of the even-membered chains relative to the odd-membered ones).

For the N-deuterated molecules, no significant wavenumber changes were detected for the amine torsional mode (Tables 1-6, Tables IS-VIS), probably due to the weaker $\mathrm{R}-\mathrm{DN}-\mathrm{D} \cdots \mathrm{ND}_{2}-\mathrm{R}$ intermolecular interactions. However, the $\tau_{\mathrm{ND}_{2}}$ Raman bands for odd-membered molecules are consistently observed at ca. $15 \mathrm{~cm}^{-1}$ higher frequencies relative to the evenmembered ones. Moreover, a shift of ca. $100 / 50 \mathrm{~cm}^{-1}$ to lower frequencies is detected between the observed and calculated Raman $\tau_{\mathrm{NH}_{2}} / \tau_{\mathrm{ND}_{2}}$ wavenumbers, respectively. Also, the $\tau_{\mathrm{NH}_{2}}$ steady displacement associated with the increase of the polyamine chain (Figure 8) is not predicted by the theoretical calculations. In fact, the vibrational consequences of the intermolecular hydrogen bonds occurring in this kind of systems cannot be 

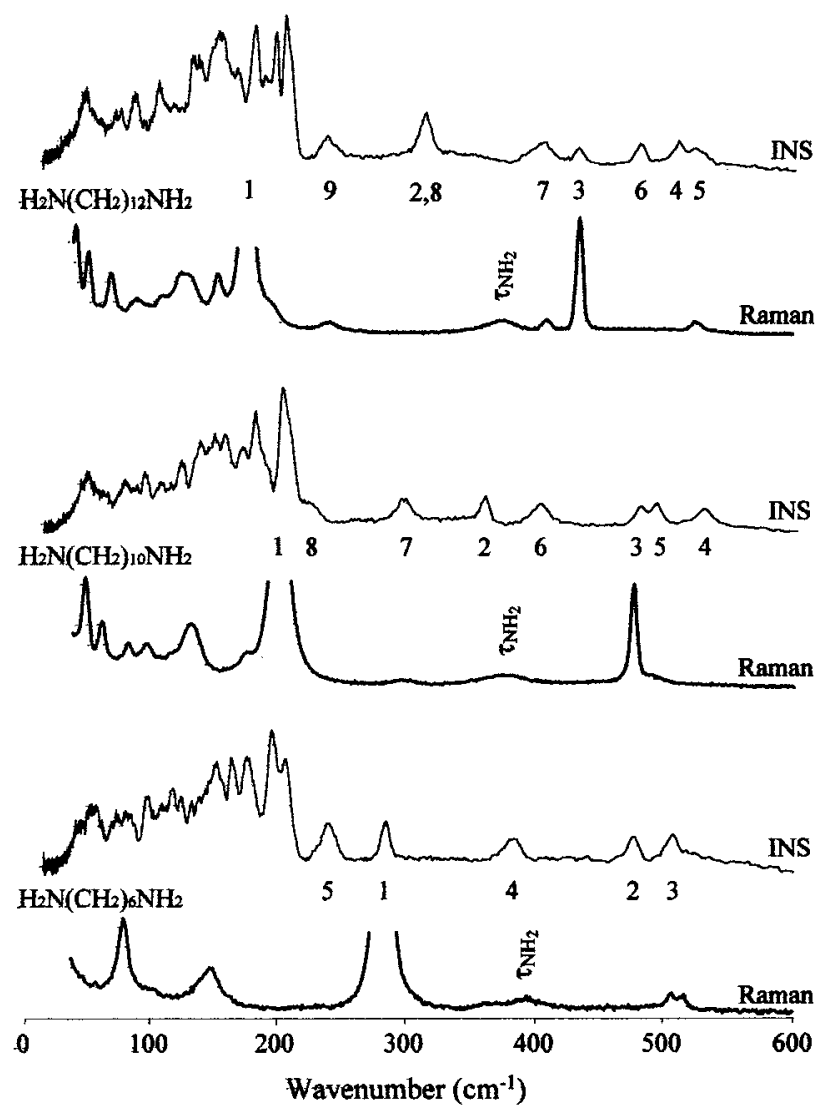

Figure 9. Experimental Raman and INS spectra (low-frequency region) for some $\mathrm{H}_{2} \mathrm{~N}\left(\mathrm{CH}_{2}\right)_{n} \mathrm{NH}_{2}$ diamines. (the numbers refer to the corresponding LAM modes).

captured by the isolated-molecule calculations used along the present study, which readily explains the above-mentioned discrepancies between calculated and experimental data.

A further consequence of the presence of $\mathrm{H}$-bonding is the lowering of the $\mathrm{N}-\mathrm{H}$ stretching modes and the concomitant wavenumber increase of the $\mathrm{C}-\mathrm{N}-\mathrm{H}$ deformations. This is quite a typical amine behavior and has been repeatedly reported for small, linear amines, for both the terminal and central nitrogen atoms ${ }^{14,19,47,48}$ (namely when going from the liquid to the solid state) and corroborates the results now obtained for the larger polyamines.

When the experimental INS and Raman data are compared (Figure 9), it is easily verified that while all the LAM's are detected by INS, in the Raman spectra, only the first LAM band is distinctly observed for all the polyamines studied. In fact, most of the higher number LAM's are either very weak or symmetry forbidden transitions in Raman spectroscopy. As the molecules get larger, however, more LAM's are progressively detected and the ones with the same number of nodes become more and more distinct (e.g., LAM 3, Figure 9).

\section{Conclusions}

The complementary use of both Raman and INS spectroscopies in the present work allowed the assignment of all the LAM's for the polyamines studied $\left(\mathrm{H}_{2} \mathrm{~N}\left(\mathrm{CH}_{2}\right)_{n} \mathrm{NH}_{2}\right.$ ( $n=2-10$ and $n=12$ ), spermidine and spermine) both for their undeuterated and N-deuterated forms. In fact, INS is very useful for the analysis of the frequency range below $600 \mathrm{~cm}^{-1}$, where it displays a clear and intense vibrational pattern, while above around $1800 \mathrm{~cm}^{-1}$ its spectral quality begins to deteriorate. Raman spectroscopy comes into its own again in this region, thus being particularly useful for the analysis of $\mathrm{CH}$ and NH/ND stretching modes.

For the linear polyamines under study, the lowest energy conformation, in the solid state, was found to be the all-trans one. The DFT calculations performed at the B3LYP/6-31G* level adequately mimicked this kind of systems, leading to a particularly good agreement between the calculated and experimental spectra. This allowed a confident assignment of the observed Raman and INS patterns.

The present study contributes to a better understanding of the conformational behavior of linear polyamines, which, in the solid state, is strongly determined by the occurrence of intermolecular $\mathrm{R}-\mathrm{HN}-\mathrm{H} \cdot \cdots \mathrm{NH}_{2}-\mathrm{R}$ hydrogen-type interactions, mainly at the terminal $\mathrm{NH}_{2}$ groups of the chains. This kind of close contact was found to give rise either to infinite chain polymeric forms or to dimeric species, in the case of 1,2-diaminoethane.

The knowlegde of the structural preferences of biogenic polyamines is of utmost importance for the design of complexes displaying this kind of molecule as linkers between metal centers (e.g., $\mathrm{Pt}(\mathrm{II})$ or $\mathrm{Pd}(\mathrm{II})$ ), which have been found to act as rather efficient anticancer agents (often even overcoming the cytotoxic effect of the drugs under clinical use).

Acknowledgment. M.P.M. and L.A.B.C. acknowledge financial support from the Portuguese Foundation for Science and Technology, Project PBIC/C/QUI/2219/95. We thank Prof. B. S. Hudson and Dr. Chris Middleton (Syracuse University, Syracuse, NY) for help and discussions on the calculation of the INS spectra from ab initio results.

Supporting Information Available: Tables comprising Raman and INS experimental and calculated wavenumbers for the diamines $\mathrm{H}_{2} \mathrm{~N}\left(\mathrm{CH}_{2}\right)_{n} \mathrm{NH}_{2}(n=6-10, n=12)$, in the lowfrequency region, as well as corresponding assignments. This material is available free of charge via the Internet at http:// pubs.acs.org.

\section{References and Notes}

(1) Pegg, A. E. Cancer Res. 1988, 48, 759.

(2) Heby, O.; Persson, L. Trends Biochem. Sci. 1990, 15, 153.

(3) Tamori, A.; Nishiguchi, S.; Kuroki, T.; Koh, N.; Kobayashi, K.; Yano, Y.; Otani, S. Cancer Res. 1995, 55, 3500.

(4) Auvinen, M.; Passinen, A.; Anderson, L. C.; Holtta, E. Nature 1992, $360,355$.

(5) Janne, J.; Alhonen, L.; Linonen, P. Ann. Med. 1991, 23, 241.

(6) Nishioka, K. Polyamines in Cancer: Basic Mechanisms and Clinical Approaches; Springer-Verlag: Germany, 1966.

(7) O’Brien, T. G.; Megosh, L. C.; Gilliard, G.; Soler, A. P. Cancer Res. 1997, 57, 2630.

(8) Porter, C. W.; Sufrin, J. R. Anticancer Res. 1986, 6, 525.

(9) Porter, C. W.; Bergeron, R. J. Progress in Polyamine Research; Plenum: New York, 1988.

(10) Auvinen, M.; Paasinen, A.; Anderson, L. C.; Holtta, E. Nature 1992, 360,355 .

(11) Moshier, J. A.; Dosescu, J.; Skunca, M.; Luk, G. D. Cancer Res. 1993, 53, 2618.

(12) O’Brien, T. G.; Megosh, L. C.; Gilliard, G.; Soler, A. P. Cancer Res. 1997, 57, 2630.

(13) Rauter, H.; Di Domenico, R.; Menta, E.; Oliva, A.; Qu, Y.; Farrell, N. Inorg. Chem. 1997, 36, 3919 and references therein.

(14) Batista de Carvalho, L. A. E.; Amorim da Costa, A. M.; Duarte, M. L.; Teixeira-Dias, J. J. C. Spectrochim. Acta 1988, 44A, 723.

(15) Batista de Carvalho, L. A. E.; Amorim da Costa, A. M.; Teixeira-Dias, J. J. C. J. Mol. Struct. (THEOCHEM.) 1990, 205, 327.

(16) Batista de Carvalho, L. A. E.; Teixeira-Dias, J. J. C.; Fausto, R. Struct. Chem. 1990, 1, 533.

(17) Bertoluzza, A.; Fagnano, C.; Finelli, P.; Morelli, M. A.; Simoni, R.; Tosi, R. J. Raman Spectrosc. 1983, 14, 386.

(18) Ghazanfar, S. A. S.; Edsall, J. T.; Myers, D. V. J. Am. Chem. Soc. 1964, 86, 559. 
(19) Batista de Carvalho, L. A. E.; Lourenço, L. E.; Marques, M. P. M. J. Mol. Struct. 1999, 482-483, 639 and references therein.

(20) Batista de Carvalho, L. A. E.; Marques, M. P. M. Unpublished results.

(21) Marques, M. P. M.; Batista de Carvalho, L. A. E. COST 917: Biogenically Active Amines in Food; Morgan, D. M. L., White, A., SánchezJiménez, F., Bardocz, S., Eds.; European Comission: Luxemburg, 2000; Vol. IV, p 122.

(22) Parker, S. F.; Braden, D. A.; Tomkinson, J.; Hudson, B. S. J. Phys. Chem. B 1998, 102, 5955.

(23) Braden, D. A.; Parker, S. F.; Tomkinson, J.; Hudson, B. S. J. Chem. Phys. 1999, 111, 429

(24) www.isis.rl.ac.uk

(25) Frisch, M. J.; Trucks, G. W.; Schlegel, H. B.; Scuseria, G. E.; Robb, M. A.; Cheeseman, J. R.; Zakrzewski, V. G.; Montgomery, J. A., Jr.; Stratmann, R. E.; Burant, J. C.; Dapprich, S.; Millam, J. M.; Daniels, A D.; Kudin, K. N.; Strain, M. C.; Farkas, O.; Tomasi, J.; Barone, V.; Cossi, M.; Cammi, R.; Mennucci, B.; Pomelli, C.; Adamo, C.; Clifford, S.; Ochterski, J.; Petersson, G. A.; Ayala, P. Y.; Cui, Q.; Morokuma, K.; Malick, D. K.; Rabuck, A. D.; Raghavachari, K.; Foresman, J. B.; Cioslowski, J.; Ortiz, J. V.; Stefanov, B. B.; Liu, G.; Liashenko, A.; Piskorz, P.; Komaromi, I.; Gomperts, R.; Martin, R. L.; Fox, D. J.; Keith, T.; Al-Laham, M. A.; Peng, C. Y.; Nanayakkara, A.; Gonzalez, C.; Challacombe, M.; Gill, P. M. W.; Johnson, B. G.; Chen, W.; Wong, M. W.; Andres, J. L.; Head-Gordon, M.; Replogle, E. S.; Pople, J. A. Gaussian 98, revision A.3; Gaussian, Inc.: Pittsburgh, PA, 1998.

(26) Russo, T. V.; Martin, R. L.; Hay, P. J. J. Phys. Chem. 1995, 99, 17085

(27) Ignaczak, A.; Gomes, J. A. N. F. Chem. Phys. Lett. 1996, 257, 609

(28) Cotton, F. A.; Feng, X. J. Am. Chem. Soc. 1997, 119, 7514.
(29) Wagener, T.; Frenking, G. Inorg. Chem. 1998, 37, 1805.

(30) Ignaczak, A.; Gomes, J. A. N. F. J. Electroanal. Chem. 1997, 420, 209.

(31) Cotton, F. A.; Feng, X. J. Am. Chem. Soc. 1998, 120, 3387.

(32) Lee, C.; Yang, W.; Parr, R. G. Phys. Rev. 1988, B37, 785.

(33) Miehlich, B.; Savin, A.; Stoll, H.; Preuss, H. Chem. Phys. Lett 1989, 157, 200.

(34) Becke, A. Phys. Rev. 1988, A38, 3098

(35) Becke, A. J. Chem. Phys. 1993, 98, 5648.

(36) Hariharan, P. C.; Pople, J. A. Theor. Chim. Acta 1973, 28, 213.

(37) Francl, M. M.; Pietro, W. J.; Hehre, W. J.; Binkley, J. S.; Gordon,

M. S.; DeFrees, D. J.; Pople, J. A. J. Chem. Phys. 1982, 77, 3654.

(38) Peng, C.; Ayala, P. Y.; Schlegel, H. B.; Frisch, M. J. J. Comput. Chem. 1996, 17, 49.

(39) Mirkin, N. G.; Krimm, S. J. Phys. Chem. 1993, 97, 13887 and references therein.

(40) Taylor, R.; Kennard, O. J. Am. Chem. Soc. 1982, 104, 5063.

(41) Steiner, T. Chem. Commun. 1997, 727.

(42) Giglio, E.; Liquori, A. M.; Puliti, R.; Ripamonti, A. Acta Crystallogr. 1966, 20, 652

(43) Giglio, E.; Liquori, A. M.; Puliti, R.; Ripamonti, A. Acta Crystal$\log r$. 1966, 20, 683

(44) Batista de Carvalho, L. A. E. Ph.D. Thesis, Coimbra, 1990

(45) Mathisen, H.; Norman, N.; Pedersen, B. F. Acta Chim. Scand. 1967, $21,127$.

(46) Barnes, J.; Franconi, B. J. Phys. Chem. Ref. Data 1978, 7, 1309 and references therein.

(47) Colthup, N. B.; Daly, L. H.; Wiberley, S. E. Infrared and Raman Spectroscopy, 2nd ed.; Academic Press: New York, 1975; pp 216-219.

(48) Batista de Carvalho, L. A. E.; Teixeira-Dias, J. J. C. J. Raman Spectrosc. 1995, 26, 653 . 